\title{
The Language in British and Slovene Football Anthems
}

\begin{abstract}
Football is probably the world's most popular game, with a huge number of fans. There are numerous ways in which football fans express dedication to their club and the feelings they have for their team, for example, wearing certain colours, waving banners and flags, and singing. Football anthems are nothing new for football fans, and many clubs have a long-established tradition of them. In this paper, I will address and compare the language in some popular British and Slovene football anthems, and attempt to explain its contribution to the creation of fan identity, to the fans' sense of belonging, unity, and motivation. The linguistic analysis identifies the linguistic resources used in football anthems to express attitudes, form bonds and create identities.
\end{abstract}

Keywords: attitudes; football anthems; identity; linguistic analysis; linguistic resources

\section{Jezik v britanskih in slovenskih nogometnih himnah}

\author{
POVZETEK
}

Nogomet je verjetno najbolj priljubljena igra na svetu, ki ima veliko privržencev. Obstaja veliko načinov, s katerimi nogometni navijači izražajo svojo pripadnost klubu, občutke, ki jih gojijo do svojih ekip, in razlike z drugimi klubi, kot so na primer, nošenje določenih barv, vihranje transparentov in zastav ter petje. Nogometne himne niso za nogometne navijače nič novega in mnogo navijaških himn ima dolgo tradicijo. Avtorica obravnava in primerja jezik v nekaterih priljubljenih britanskih in slovenskih nogometnih himnah in skuša razložiti njegov doprinos $\mathrm{k}$ ustvarjanju navijaške identitete, občutka pripadnosti, povezanosti in motivacije. Jezikoslovna analiza prepoznava jezikoslovne vire, ki so uporabljeni v nogometnih himnah z namenom, da izrazijo odnose, oblikujejo vezi in ustvarjajo identitete.

Ključne besede: nogometne himne; jezikoslovna analiza; jezikoslovni viri; odnosi; identiteta 


\section{The Language in British and Slovene Football Anthems}

\section{Introduction}

In modern society, sport promotes a sense of identity, unity, status and esteem. Additionally, it stimulates aggression, stereotyping and images of inferiority and superiority, while acting as a method of cultural bonding across national boundaries (Mangan 1996). Football, as probably the world's most popular game, is no exception to this. It is the world's universal language, transcending national borders, religion and ways of life. For instance, over three billion people, half of the planet, watched the 2014 World Cup. More than 650,000 people in England watch Premiership, Championship and Champion league games. In Slovenia, football is perhaps not as popular as it is in England, but many people still watch football games live and on TV on Saturdays, especially in the eastern part of Slovenia. One way to relate to a team as fully as possible and to show support for them is through fandom, which is extremely important not only for the fans but also for the clubs. Football fans consider themselves the team's 'twelfth man', helping the team to win and sharing responsibility for their success. The main difference between supporters (fans) and spectators concerns degrees of passion (Pooley 1978). Supporters express their dedication to the club in various ways, such as wearing club colours, waving banners and flags, singing, clapping, uttering paroles, performing choreography, provoking opposition fans and reacting to other clubs' supporters. In these ways, they also release the frustrations of everyday life. Thus, for fans, drawing attention to the differences between them and other supporters and clubs is as important as the support itself.

Football anthems as a means of support are nothing new to football fans, and many have a long tradition of them. They are assumed to play an important role in the process of the clubs' struggle for dominance. Many football anthems are carefully chosen, adapted or invented to convey difference, passion, support and unity. Singing in unison with other supporters is a powerful performance with the aim of creating a sense of unity and belonging; in mass singing, the effect of common pride is intensified and the ego disappears. To fulfil the needs of the crowd, anthems have to be melodic and easy to memorise, but nevertheless powerful in rhythm and content. Football anthems express values, experiences and emotions which help define a group's identity and promote solidarity. According to Frith, "music seems to be a key to identity because it offers, so intensely, a sense of both self and others, of the subjective in the collective" $(1996,110)$. Slobin (1993) explains that football songs invoke pride and ambition, while inviting fans to lose themselves in the group - to create a collective identity. In addition, he speaks of "cultural brandnaming", of music and songs having a symbolic function as identity emblems. Social identity is defined as "that part of an individual's self-concept which derives from [...] knowledge of [...] membership of a social group (or groups) together with the value and emotional significance attached to that membership" (Tajfel 1978, 63). Moreover, it is defined as "a set of meaning applied to the self in a social role or situation defining what it means to be who one is" (Burke 1991,837 ), whereby "the core of an identity is the categorization of the self as an occupant of a role" (Stets and Burke 2000, 2).

I will explore the use of language in some British and Slovene football anthems in order to show how their language motivates, constructs and reflects the identity of the football fan and a sense of unity, authenticity, friendship and belonging. The analysis of language takes on the 
perspective that linguistic choices do not only provide information but primarily make meanings within a social context. The analysis also relies on the definition of a discourse as one of the active forms of acting on the world, and a form with which people act upon each other (a text is a medium of discourse) (Levinson in Fairclough 1992, 63). Football anthems are no exception to this. Thus, the language in anthems is also socially shaped; it reflects ideology, including values, in the sense "of who we are, what we stand for, what our values are and what our relationships with others are" (Oktar 2001, 314). More specifically, the linguistic choices in the language system depend on social functions that humans want or need to accomplish (Halliday 2003). Since football anthems usually serve to motivate, express support and create a sense of belonging and unity, the language is expected to serve this purpose. My aim is thus to explore the language use in football anthems within the social context - namely, by "recovering the social meanings expressed in discourse by analysing the linguistic structures in the light of their interactional and wider contexts" (Fowler et al. 1979, 195-96). The analysis focuses on the evaluative language, i.e. on the interpersonal meanings realised through various linguistic elements, such as repetition, attitudinal lexis, the grading of attitudes as quantification, enhancement, infused lexis and specificity, and counter-expectancy elements and denials as engagement elements.

Before moving to the analytical section of the paper, it is necessary to explain briefly the identity of the football fan and the background of anthems.

\section{Football Fandom}

Football began in England and is considered England's national sport. It has its own tradition, history and language. As this tradition is particularly long-established, football fandom in England is especially strong. Even though the audience is still predominately male, the number of female spectators is growing. Football is also strongly rooted in terms of geography. As Duke and Crolley (1996) note, it captures the notion of an imagined community perfectly. Interestingly, local identity in England is even stronger than a sense of Englishness (Bryant 2006).

Football spread to Slovenia from Vienna - at that time the capital of the Austro-Hungarian Empire, of which Slovenia was a part - and the word "football" was mentioned for the first time in 1900. When Slovenia was part of Yugoslavia, many smaller and larger football clubs were established. During that period, the Slovene football club Olimpija played regularly in the top Yugoslav league, while Maribor FC played there occasionally. After Slovenia gained independence in 1991, football remained popular, which is also reflected in the establishment of a fandom with the aim not only of supporting football clubs and teams but also of emphasising patriotism, unity, fan identity and a sense of belonging within the community.

The most famous supporters in Slovenia are: the Viole, who support Maribor FC, the football club from the main town of the north-eastern Slovenian region of Styria; and the Green Dragons, who support the football club Olimpija from the capital city Ljubljana. The name Viole relates to the club's colour (violet), whereas the name Green Dragons relates to the dragon - the symbol of Ljubljana, representing power, courage and greatness. The Maribor and Olimpija clubs have a long tradition of football rivalry. Since Olimpija FC is a Ljubljana club, the rivalry between Olimpija FC and Maribor FC is even greater, especially now that the town of Maribor has been much more severely affected by the economic crisis than Ljubljana, suffering a high rate of unemployment. Perhaps unsurprisingly, football and its fans are often manipulated for political gain. Since Maribor FC is considered to be more successful than Olimpija FC 
(winning the Slovenian premiership several times, playing in both the UEFA Europa League and the Champions League), the club has become an object of strong identification for the local community on the basis of its success and ensuing pride - something that many people also use to cope with their personal and economic problems.

According to Lalić (1993), the main characteristics of a fan include showing interest in watching football, intense identification with the club, readiness to help the club and attempting to influence other people to accept their way of supporting the club. Fandom allows individuals to be part of the game - to relate to a team - without requiring any special skills (Branscombe and Wann 1991). Furthermore, supporters share the view that the value they get most from football is primarily social in nature, including the feeling of being part of a locality/community (solidarity), friendship (camaraderie), having a sense of community with other people, being a part of an informal 'family' and sharing experience with other supporters (Brown et al. 2010). Moreover, feelings of self-esteem and social prestige become intensified through supporting a team (Zillmann et al. 1989). The modern fan community, as a well-organised group organisation with (official) membership, a shared passion (for football) and a wish to further explore this passion by learning and finding new (creative) ways to support the club, as well as to share knowledge about supporting (for instance, new anthems, tools, information about football and club), could perhaps be regarded as community of practice - which is, according to Wenger (2006), described as groups of people sharing a passion for something and the wish to explore that passion further.

The following football anthems were used as sites of linguistic exploration:

English football anthems

“Glory Glory Manchester United” (Manchester United FC)

"You'll Never Walk Alone" (Liverpool FC)

"Blue Moon" (Manchester City FC)

"Blue Day" (Chelsea FC)

"I'm Forever Blowing Bubbles" (West Ham FC)

"The Greasy Chip Butty" (Sheffield United FC)

"Marching on Together" (Leeds United FC)

Slovene football anthems

"Hej hej hej Viole" (Maribor FC)

"Olimpija” (Olimpija FC- Ljubljana)

\section{Background of Anthems}

The anthem "Glory Glory Manchester United" uses the tune to "The Battle Hymn of the Republic," whereby Hallelujah in the chorus "Glory, Glory, Hallelujah" is replaced by the name of the favoured team. "The Battle Hymn of the Republic" is a song by the American writer Julia Ward Howe. The song links the judgment of the wicked (New Testament, Rev. 19) with the American Civil War. Since that time, it has become an extremely popular and well-known American patriotic song. Even though it is unclear why this American song was adopted and adapted as the Manchester United anthem, the reason may lie in the lyrics. A 
parallel can be drawn between the patriotism of the Union soldiers, who are urged to face death in their continuous fight against the Southern Confederacy and the fans' patriotism, or sense of belonging and loyalty, towards their home - the club.

The anthem "Blue Moon" originates from the great American song-writing partnership of composer Richard Rodgers and lyricist Lorenz Hart. The music for the song was written in 1934 to be sung in the film Hollywood Party under the title "Prayer." Its first rock and roll version was by Elvis Presley in 1956. There are over 60 versions of the song (by Louis Armstrong, Frank Sinatra, Dean Martin, Bob Dylan, Rod Stewart, and the list goes on). The song has also been adopted by City fans as their anthem - an unusual choice as far as football anthems go because the original is relatively mellow and gentle - although City fans have made it their own and belt it out with fervour.

The song "You'll Never Walk Alone" is a show tune from the 1945 Rodgers and Hammerstein's musical Carousel. As a football anthem, it was used for first time in 1963 when the Liverpudlian Merseybeat group Gerry and the Pacemakers reached No 1 in the singles chart. Liverpool fans still sing this anthem as their final ritual before kick-off at every home game.

The song "Blue Day" was a single released by the English singer Suggs, in collaboration with the players of Chelsea, in 1997. It reached number 22 in the UK Singles Chart.

The song "The Greasy Chip Butty Song” is a football chant originally sung by the supporters of Sheffield United football club to the tune of "Annie's Song” by John Denver, glorifying the delights of life in Sheffield.

The song "I'm Forever Blowing Bubbles" is originally a popular American song which debuted in the musical The Passing Show of 1918 in 1918. The melody frequently appears in animated cartoon sound tracks when bubbles are visible. The song features extensively in the 1931 prohibition gangster movie The Public Enemy. It was adopted by West Ham supporters in the late 1920s. Some West Ham United fans sing alternative lyrics. The second line "nearly reach the sky" is changed to "they reach the sky", "then like my dreams" is also changed to "and like my dreams".

The song "Marching on Together" is unlike most other anthems, which have simply used the original music of another song and altered the lyrics. The song is an original composition by Les Reed and Barry Mason with the title "Leeds!Leeds!Leeds!" The song was first released in 1972 as a B-side and coincided with the team reaching the 1972 FA Cup Final. The song on the A-side of the same record was titled "Leeds United."

The song "Hej hej hej Viole" was written by the band Čudežna polja in 1992 to copy the tradition of big European football clubs. It was written shortly after the establishment of the Viole fan group.

The song "Olimpija” was written by the famous Slovenian rock singer Pero Lovšin.

\section{Linguistic Analysis}

In this section, I analyse repetition, attitudinal lexis, graders and engagement elements as the most typical linguistic features used in the anthems to help create the values of fandom, unity, motivation, solidarity, friendship and belonging. 


\subsection{Repetition}

A frequent linguistic feature in the anthems is repetition, in particular, repetition of the same words, which is used primarily to emphasise and intensify positive values, such as the supporters' commitment to the club and fan-group. Personal involvement as a fan is also highly important. In most cases, the repeated words are grammatically realised as: thing + thing, as in the Manchester United anthem (glory glory); process, as in the Liverpool anthem (walk), Chelsea anthem (waited, gonna), Leeds United (gonna), Olimpija anthem (hear) and Maribor anthem (score); epithet, as in the Manchester United anthem (famous); and attribute in a relational clause, as in the Leeds United anthem (proud). In addition, the values of victory and success are intensified by the repetition of attitudes realised through different grammatical forms, for instance, thing and process in zmago prineso [bring victory], zmagal bo Maribor [Maribor is going to win], šampion [champion] in the Maribor anthem.

The repetition of personal pronouns is also frequently used, especially of the pronoun "we". In the anthems, both the exclusive and inclusive pronoun "we" are used. In most cases, the pronoun "we" performs the exclusive function, excluding the team/club from the propositions and in this way creating a distance between the fans and the club/players, hence emphasising the value of fandom, as in the Chelsea anthem (we would leave you never) and Leeds United anthem (we're gonna stay with you forever). This pronoun also emphasises the values of pride, patience and victory, as in the Chelsea anthem (we've waited so long) and Leeds United anthem (we're gonna see you win, we are so proud). The inclusive "we", encompassing both the fans and the club/team, on the other hand, foregrounds the fans' identification with the club and the team. This is particularly evident in the Manchester United (we're the famous MAN United) and Chelsea anthems (when we make it). Interestingly, however, the use of pronouns in the Olimpija anthem is rare (računite na nas [count on $u s$ ]). ${ }^{1}$ Besides encouraging the team, the supporters motivate themselves and other spectators to support the team, express their aims and ambitions and celebrate their joint success, as in the Manchester United anthem (we're the boys in red and we're on our way to Wembley).

Joint success is particularly emphasised in the Maribor anthem (dajmo še en gol [let's score another goal]), the Manchester United anthem (we're the famous Man United), and the Chelsea anthem (when we make it). Interestingly, in the Maribor anthem, the supporters emphasise their share in success much more than in other anthems (Viole Štajerske zmago prineso na Štajersko [Styrian Viole bring victory to Styria]). Besides communicating with the team and fellow fans, supporters communicate directly with the opposing side with (modulated) commands, often with a mildly threatening and intimidating tone, as in the Chelsea anthem (you should hear the Chelsea roar) and Maribor anthem (poglejte na semafor [look at the scoreboard]), and with the pronoun you, as in the Olimpija anthem (pa še neki ti povem [and let me tell you something else]).The repetition of the possessive pronoun "our" is typical of the Maribor anthem, emphasising fans' commitment and joy (za Maribor nam srce gori [our heart burns for Maribor], srca naša so srečna [our hearts are happy]). The values of fandom, union and solidarity are occasionally emphasised with the adverb "together" instead of the pronoun "we" as, for instance, in the Leeds United (marching on together, we've been through it all together) and Chelsea anthems (it'll be together). Even though "marching on" was originally borrowed from the song "The Battle Hymn of the Republic" (our God is marching on) in the Manchester United anthem, its use in the Leeds United anthem may

It should be acknowledged that Slovenian is a subject-drop language; the verb can appear on its own. 
imply that it was also borrowed from the same song, as it may evoke associations of God with the team/club and its success. The use of the pronoun " $\mathrm{I} / \mathrm{me}$ " is particularly strong in the Manchester City and West Ham anthems, emphasising the fan's individuality rather than their membership in a fan group ( $I$ looked everywhere, $I \mathrm{~m}$ forever blowing bubbles, $I$ really could care for, $I$ heard somebody). However, in the Manchester City anthem, the transition from the alienated individual to the non-alienated member of a group is well expressed through the repeated use of "I/me" (saw me standing alone - now Im no longer alone).

The repetition of pronouns "you" and "your" is typical of the Liverpool anthem, encouraging the team, expressing commitment to them and emphasising the value of pride (you'll never walk alone, hold your head up high). The pronouns "you" and "your" are used to address the club and the team directly, hence creating a closer contact between the fans and the team/club. In the Leeds United anthem, love towards the club is conveyed directly (we love you Leeds!Leeds!Leeds!). Despite only one occurrence of "you" in the Sheffield United anthem (you fill up my senses), its placement in the prominent first position of the clause right at the beginning of the anthem emphasises the club's fulfilling role in the fan's life - followed by six comparisons of this fulfilment with the delights and pleasures of life, such as cigarettes, a night out and food (like a gallon of Magnet). Even though comparisons occur rarely in anthems, the comparison with "the Busby babes" in the Manchester United anthem emphasises the values of youth, pride, talent and skill. Manchester United is particularly proud of their home players and the football school from which many of their famous players emerged. Since the shaping of identity through common ideas of the greatness and heritage of one's club is significant, to become a fan means to become immersed in the history and traditions of the club and its players. Some encyclopaedic historical and statistical knowledge about the team and club is expected from a 'true fan'.

The value of history and the past is particularly prominent in the anthems of Manchester United and Chelsea, whereas in both Slovene anthems and in some other English ones this value seems to play no role because either the club's history was not that rich in terms of success or the anthems prefer to focus on the present and future success. The Manchester anthem also features some famous managers who experienced FA Cup glory with the club in the past (in Seventy-Seven it was Docherty, Atkinson will make it Eighty-Three). The time reference points to the glorious years of winning. Restored glory as well as the memories of the club's difficult past times are emphasised in the Chelsea anthem (Ossie and co. restored our pride, we've got some memories). In the Manchester United anthem, the pronoun "you" conveys distance by imitating a dialogue with the supporters of other clubs, often as a mild threat (you've got to hear the masses sing with pride). The pronouns "you" and "your" and their use in contracted forms (you're, we've) as well as the short forms of some other words (the reds, 'cause) imitate (informal) dialogue. The use of the pronoun "they" occurs in the West Ham anthem, referring to a fan's dreams (they fly so high, they fade and die), and in the Leeds United anthem, referring to the team, hence making a clear distinction between the fans and the team (they're the greatest in the land). Additionally, the repetition of extent and time quantifiers, of the club's name and of prepositions in phrasal verbs occur, intensifying the value of unbroken support and commitment, as in the Leeds United anthem (everywhere, everyday, Leeds), Olimpija anthem (Olimpija) and Manchester United anthem (go marching on, on, on). In some cases, for instance, dual intensification occurs (intensification via the comparative like and intensification via listed comparisons), as in the Sheffield United anthem (like a packet of Woodbines, like a good pinch of snuff, like a greasy chip butty). By repeating the comparison in the Sheffield United anthem, the dubious delights of Sheffield town and the attitudes of fulfilment and satisfaction are emphasised. The repetition of 
the club's name should raise associations with greatness and pride. The most frequent repetition of the club's name occurs in the anthems of Leeds, Olimpija, Manchester United and Chelsea. Furthermore, the repetition of a denial is also used to intensify the feeling of unhappiness before becoming a fan, as in the Manchester City anthem (without a dream in my heart, without a love of my own).

Besides the pronouns, the repetition of commands realised as imperatives emphasises support, victory and reliance, as seen in the examples below. Also commands are used to motivate, to encourage, and to threaten directly, hence emphasising the value of supporting the team, as shown in (1). For instance, the value of support is expressed strongly with the command "računite na nas [count on us]" in the Olimpija anthem. This command bears a strong resemblance to the title of a song from Yugoslav times, namely, "Računajte na nas" by Djordje Balašević, in which youth and reliance on youth were emphasised.

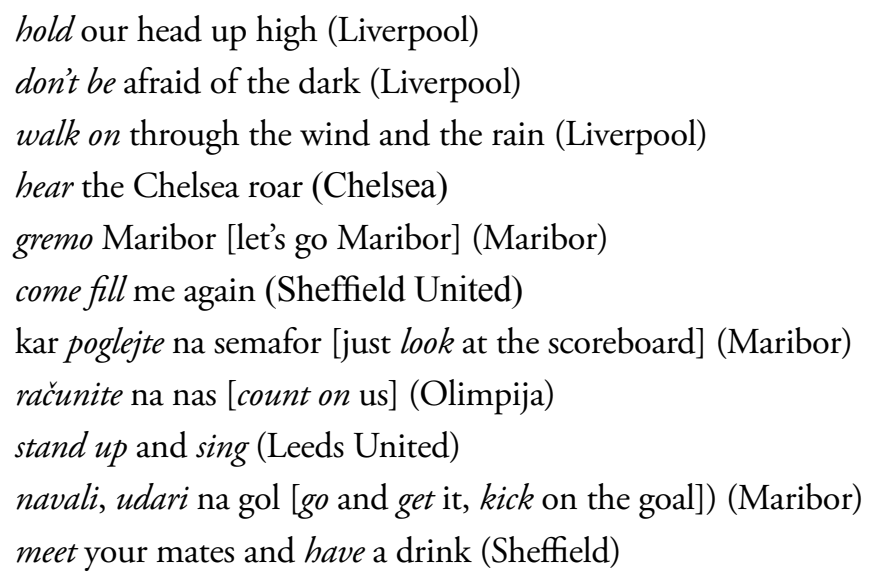

By repeating the commands "meet your mates and have a drink" (Chelsea anthem), the social element of fandom as well as friendship and the relaxed atmosphere at games are particularly emphasised. The use of the informal expression "mate" enhances the effect.

The repetition of nouns forming idioms and of prepositional phrases is also used to emphasise loyalty and solidarity, as in the Leeds (our ups and downs) and Liverpool anthems (through the storm, through the rain).

Similarly, the repetition via listing of Yorkshire informal expressions "gallon of Magnet", "packet of Woodbines", "snuff" and "chip butty" which stand for beer, cigarettes and tobacco, and a sandwich made with bread or a bread roll and chips, points to the delights of Sheffield town, culminating with the joy of supporting the club, and foregrounding local identity and authenticity.

\subsection{Attitudinal Lexis}

Anthems are rich in positive attitudes and values which are expressed explicitly through lexical elements realised grammatically as things, processes and attributes in relational clauses. In particular, pride, hope, love, happiness, skill, victory and fame are emphasised. The values of 
victory and skill are particularly noticeable in the Maribor anthem (najboljši smo [we're the best], Maribor-šampion [Maribor-champion], zmago prinesejo na Stajersko [bring victory to Styria], zmagal bo Maribor [Maribor is going to win]), and in the Leeds United anthem (we're gonna see you win, they are the greatest in the land). Other examples are listed in (2):

(2)

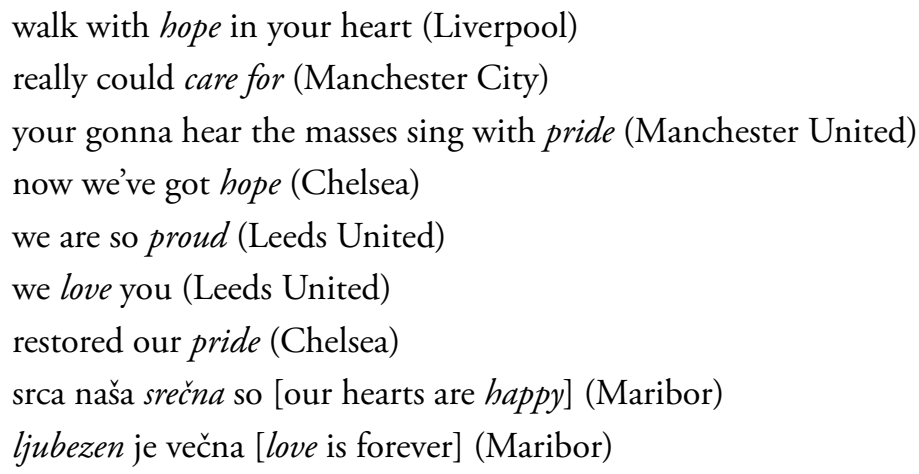

Furthermore, many attitudes and values are expressed implicitly, mainly as metaphors and via intensifiers foregrounding pride, fame, patience, love, victory, skill and fulfilment, as in the examples listed in (3):

(3)

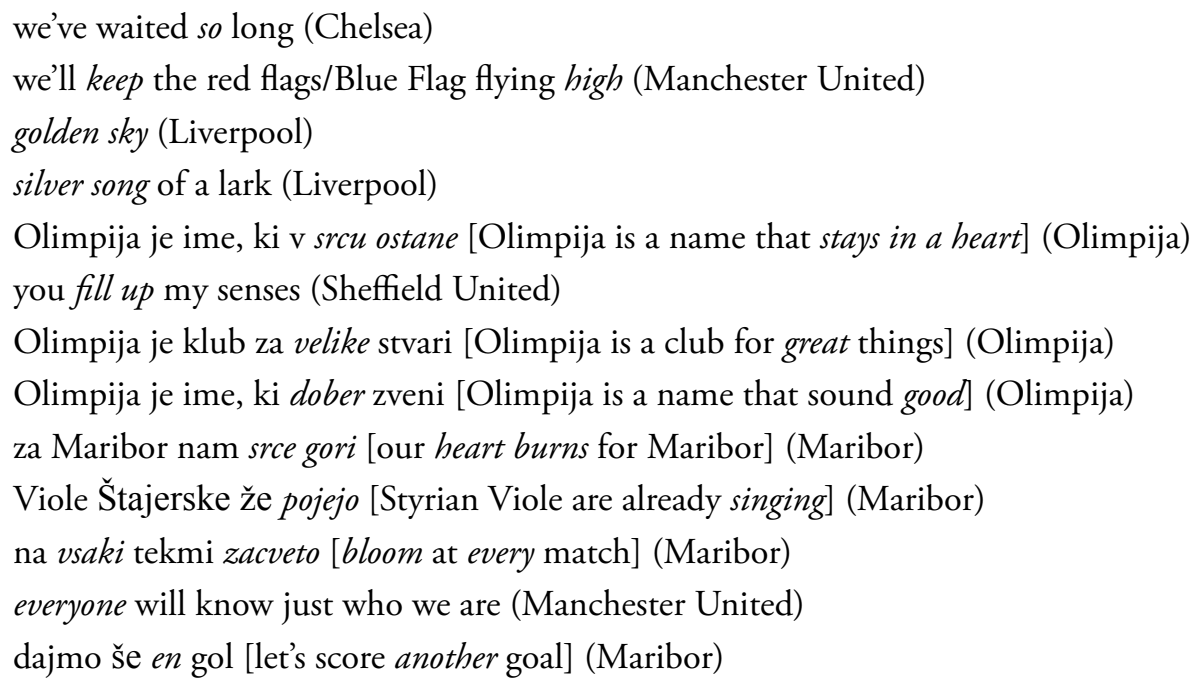

The feeling of one and only true love towards football and fandom is emphasised with the grader "only" in the Manchester City anthem (only one my arms will ever hold) and in the Chelsea anthem (only place to be every other Saturday), leaving no room for other priorities in a fan's life, at least not on Saturdays. The value of victory is particularly strongly emphasised metaphorically in "at the end of the storm there is a golden sky" in the Liverpool anthem, whereby the storm could be interpreted as a metaphor for the match - battle/struggle; whereas a golden sky may be associated with a gold medal, predicting a positive outcome - victory - and symbolising hope. 
Gold and silver have an undoubtedly positive connotation, and hence a motivating effect (the sweet silver song of a lark, the moon had turned to gold).

Even though the majority of attitudes are positive, some negative attitudes are expressed, such as fear, unhappiness, lack of dreams and hope and struggle. Most of these are expressed to foreground the fan's feeling of alienation before matches or before becoming a fan, as in the examples listed in (4):

(4)

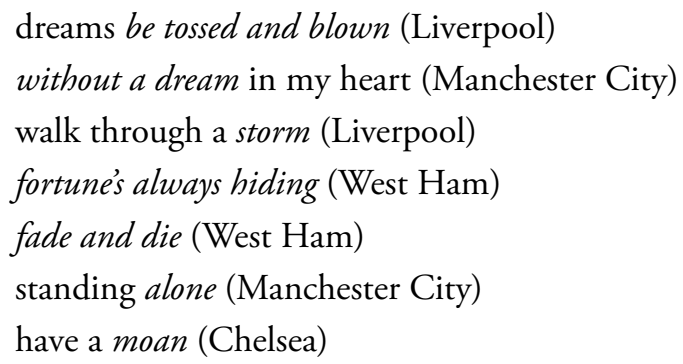

In the Olimpija anthem, negative evaluation targets the capital city of Ljubljana with the expression realised as the attribute in the relational clause "bolna [sick]" in the statement "Lublana je bulana [Ljubljana is sick])". The statement is also the title of a well-known song by the Slovene band Pankrti, whose lead singer is the author of the Olimpija anthem.

\subsection{Attitudinal Grading}

Attitudinal meanings can be graded up or down in terms of degree of intensity. Many attitudes are upgraded through stressing the importance of being loud and numerous, and of loyalty, success and greatness. Attitudinal meanings are mainly upgraded by:

- quantification as amount and extent

hear the masses sing with pride (Manchester United)

stay forever, the greatest in the land (Leeds United)

fortune's always hiding (West Ham)

restored our pride (Chelsea)

na vsaki tekmi zacveto [bloom on every match] (Maribor)

ljubezen večna [eternal love] (Maribor)

Olimpija se sliš dones in se je slišal včeri [Olimpija is heard today and was heard yesterday] (Olimpija)

Olimpija se sliš daleč [Olimpija is heard far] (Olimpija)

dajmo še en gol [let's score another goal] (Maribor)

would leave you never (Chelsea)

everywhere, everyday (Leeds United)

every other Saturday (Chelsea)

your gonna see us all from far and wide (Manchester United) 
As extent quantifiers, the future tense, the verb "keep" conveying continuity, the progressive aspect, and the repetition of prepositions also feature strongly, indicating definite victory, success, support and happiness (zmagal bo Maribor [Maribor is going to win] (Maribor), Viole Štajerske že pojejo [Styrian Viole are already singing, singing] (Maribor), we're gonna see you win (Leeds United), gonna stay with you forever (Leeds United), marching on on on (Manchester United), keep flags flying high (Manchester United). Similarly, the conditional "when we make" is used less tentatively than "if we make it" in the Chelsea anthem. The determination to succeed and support expressed with the future tense is especially strong in the Leeds United anthem.

- enhancement (the grading of attitudinal meaning is encoded in the circumstantial element)

flags flying high (Manchester United)

hold your head high (Liverpool)

shout it loud (Liverpool)

Olimpija se sliš na glas [Olimpija is heard loud] (Olimpija)

- infused lexis (the degree of intensity is conveyed in a single lexical element)

love (Liverpool, Manchester City)

srce gori [heart burns] (Maribor)

glory (Manchester United)

šampion [champion] (Maribor)

tribuna trese se [stadium is shaking] (Maribor)

roar (Chelsea)

Since supporters differentiate themselves from spectators by passion, the degree of passion they experience is highly important, as in the Maribor anthem (srce gori [heart burns], trese se [(the stadium) is shaking]). This is also evident in the emphasising of how loud and numerous the supporters are (shout it loud (Leeds United), masses sing (Manchester United), hear Chelsea roar, from far and wide (Manchester United), Ljudski vrt hrumi [Ljudski vrt is roaring] (Maribor anthem), Olimpija se sliš deleč in sliš se na glas [Olimpija is heard far and it is heard loud]). In these ways, the value of difference is foregrounded.

- isolated intensifiers (so proud - Leeds United) and comparisons (the greatest - Leeds United; najboljši [the best] - Maribor)

\subsection{Grading Attitudes as Specificity: Names, Colours and Loca- tions}

Attitudes can be also graded in terms of sharpening or softening of experiential categories. This means that certain non-gradable sources become gradable, hence expressing attitudes indirectly (Martin and Rose 2003). In the anthems, the use of language which conveys the names of clubs, stadiums and their location, and team colours, thus specifically, helps trigger and intensify positive attitudes and values of belonging and familiarity. The names of clubs and stadiums are mentioned particularly in the anthems of Chelsea, Manchester United, Leeds United, Maribor and Olimpija. It is imperative for a fan to be at the stadium every other Saturday. Interestingly, Wembley Stadium is mentioned in the Manchester anthem to emphasise the venue of the FA Cup and all major cup 
competitions in English football. Manchester has won several games there and will undoubtedly be heading also in the future because they are supposed to be the best. In the Maribor anthem, besides the name of the stadium Ljudski vrt, the location of the stadium "pod Kalvarijo [at the foot of Kalvarija]" and the geographical region "Štajerska [Styria]" are mentioned to emphasise local links and authenticity. "Kalvarija" is a hill well known to the people of Maribor as a vineyard and walking route. The Styria region is specifically mentioned to emphasise the locality of the club, as there are many people from other parts of the Styria region who support it. Similarly, the name of the capital is spelled in its dialect version "Lublana", along with some other dialect features (se sliš dones [is heard today], računite na nas [count on us], včeri [yesterday]).

In the Chelsea anthem, "the Fulham road" is mentioned as the precise location of the stadium, which everybody is expected to know. Even though the club is addressed in most anthems (Olimpija je klub [Olimpija is a club], go with Leeds United, sing for Leeds United, heja heja NK Maribor [hey hey FC Maribor], Maribor-šampion [Maribor-champion]), the team (the players) are occasionally addressed and evaluated, as in the Leeds United anthem (give the boys a hand, they're the greatest, we're gonna see you win) and in the Maribor anthem (vijolice zacveto [violets start blooming]). The patronising lexis (we're the boys in red, give the boys a hand) further intensifies the values of unity and togetherness. Additionally, stadiums are not only spiritual homes but also battlefields - a battle between the opposing teams and opposing supporters. However, success is only rendered possible when the team and fans unite. The stadium's resemblance to a battlefield can also be seen, for instance, in the expressions marching, roaring, storm and rain. Other elements play an equally important role, for example, elements of nature, for instance, flowers, storm, rain, wind, sky and air occur in the anthems of Liverpool, Maribor and West Ham.

The strong identification of the fan with the club's colour is noticed particularly in the anthems of Manchester United (we're the boys in red, as the reds go marching on), Maribor (vijolice [violets]) and Chelsea (the Blue Flag, now even Heaven is blue, gonna make this a Blue Day, blue tomorrow), where fans emphasise the nobility of the club next to victory and success. In the Maribor anthem, the club's colour is repeated several times - metaphorically as the name of the supporters, Viole, and as flowers (violets), emphasising success not only in spring - the season of violets - but in every match. Interestingly, the name of the supporters appears only in the anthems of Manchester United and Maribor. The definite article in "the reds," meanwhile, evokes the value of fame and familiarity. Similarly, fame and familiarity are emphasised in the proposition "everyone will know just who we are" in the Manchester United anthem.

\subsection{Engagement: Counter-Expectancy and Denial}

Engagement is a system used by writers/speakers to signal their presence in a text by adopting a position with respect to the proposals and propositions conveyed in a text (Martin and White 2005). The writers' engagement with the texts of anthems is observed in many counter-expectancy elements and denials that primarily close down the space for any alternative communication, as exemplified in (5). Additionally, counter-expectancy elements (even, but, though) trigger a feeling of surprise, while denials (not, never, without) reject the possibility of a fan's lack of commitment, support, loneliness and alienation, with the purpose of emphasising the value of supporting. For instance, strong loyalty and the determination not to betray the club by leaving are particularly obvious in the use of the maximised denial "never" in the Chelsea anthem (we would leave you never). Similarly, the Spanish expression "que sera sera" (whatever will be will 
be) in the Manchester United anthem conveys constant support regardless of whether the team wins or loses. The counter-expectancy marker "though" in "though your dreams be tossed and blown" not only encourages support but also hope and dreaming, as in the Liverpool anthem.

(5)

now even Heaven is blue today (Chelsea)

now we've got hope, it's not a dream (Chelsea)

we've waited so long but we'd wait for ever (Chelsea)

you'll never walk alone (Liverpool)

no longer alone without a dream (Manchester City)

Even though football clubs, teams and fans are united by football, the direct focus on the game is emphasised only in the Maribor's anthem (gol [goal], poglejte na semafor [look at the scoreboard]).

\section{Conclusion}

The analysis shows that the language in football anthems plays a significant role in both shaping and reflecting fan identity and fandom social values, which suggests that football anthems may not be chosen randomly. A closer observation of the language reveals that football anthems nevertheless contain a rich array of linguistic features, despite their rather simple vocabulary, which serve the purpose of fandom by expressing the values of support, union, motivation, authenticity, belonging, local identity, loyalty, success and difference, hence emphasising their importance. This array of linguistic features includes primarily repetition of pronouns, commands and denials, mentions of the club's name, colour and stadiums, attitudinal lexis, attitudinal intensification, counter-expectancy markers and denials.

The repetition of pronouns occurs mainly to emphasise positive values, such as the supporter's commitment to the club, fandom and joint success. The emphasis on fandom, on the one hand, is presented through the repetition of the exclusive pronoun "we", creating a distance between the fans and the club/team, as in the Chelsea anthem, while on the other hand, the inclusive pronoun 'we' emphasises joint success between the fans and the club/team, as in the Manchester United and Maribor anthems. Interestingly, both types of the pronoun are used in the Chelsea anthem. Additionally, in the Maribor anthem, the fan's share in success is much more prominent than in other anthems. Instead of the pronoun, unity is expressed directly with "together" in the Leeds United and Chelsea anthems. The use of the personal pronoun "I" occurs rarely in anthems; however, it features strongly in the Manchester City and West Ham anthems to foreground the individuality of the fans. The repetition of commands realised with imperatives occurs frequently in the anthems of Liverpool, Chelsea and Maribor. The aim is motivation and encouragement.

Another feature that occurs frequently is attitudinally loaded lexical elements, particularly noticeable in the anthems of Liverpool, Leeds United, Chelsea and Maribor. These lexical elements convey directly the values of pride, hope, love, happiness, skill, victory and fame. Furthermore, the same values are often expressed indirectly, mainly via metaphors and quantifiers. The Olimpija anthem is particularly rich in these lexical elements. In most anthems, attitudinal meanings are intensified primarily via quantification, emphasising the importance of being loud and numerous (as a characteristic of a committed and loyal supporter), success and greatness. The 
importance of being heard and seen is also expressed via intensifying elements of enhancement in the Manchester United, Liverpool and Olimpija anthems, whereas this importance is emphasised strongly in the Maribor anthem via infused lexis. Similarly, the future tense, the verb "keep" (conveying continuity), the progressive aspect and the repetition of prepositions functioning as quantifiers indicate victory, success and support, in particular in the anthems of Maribor, Leeds and Manchester United.

The use of language which expresses colours, names of clubs and stadiums helps trigger values of belonging and familiarity (anthems of Chelsea, Sheffield United, Leeds United, Maribor, and Olimpija). In the Maribor anthem, even the precise location of the stadium is provided (its geographical region and the name of the hill behind the stadium). Club colours feature mainly in the anthems of Manchester United, Maribor and Chelsea. For instance, in the Maribor anthem, the "violet" is repeated seven times to signal the fans' intense identification with the club, while at the same time emphasising success in every match, not only in spring, which is the season for violets to bloom.

Finally, the use of counter-expectancy markers and denials signals authorial intervention in the text, mainly to trigger a feeling of surprise towards the unexpected and to reject the possibility of the fan being alienated, or a lack of commitment or support on the part of the fan, as in the Chelsea anthem.

\section{References}

Branscombe, Nyla R., and Daniel Wann. 1991. "The Positive Social and Self-Concept Consequences of Sports Team Identification.” Journal of Sports and Social Issues 15: 115-27. doi:10.1177/019372359101500202.

Brown, Adam, Fiona McGee, Matthew Brown, and Adrian Ashton. 2010. Summary Report, The Social and Community Value of Football: Supporters Direct. Accessed October 20, 2014. http://www.supportersdirect.org/wp-content/uploads/2012/08/svoff-summary-report.pdf.

Bryant, Christopher G. A. 2006. The Nations of Britain. Oxford: Oxford University Press.

Burke, Peter. 1991. "Identity Processes and Social Stress." American Sociological Review 56: 836-49. doi: $10.2307 / 2096259$.

Duke, Vic, and Liz Crolley. 1996. Football, Nationality and the State. London: Addison Wesley Longman.

Fairclough, Norman. 1992. Discourse and Social Change. Cambridge: Polity Press.

Fowler, Robert, Bob Hodge, Gunther Kress, and Tony Trew. 1979. Language and Control. London: Routledge.

Frith, Simon. 1996. "Music and Identity." In Questions of Cultural Identity, edited by Stuart Hall and Paul du Gay. 108-27. Thousand Oaks, CA: SAGE Publications.

Halliday, Michael A.K. 2003. “The Functional Basis of Language.” In On Language and Linguistics. The Collected Works of M.A.K. Halliday, edited by Jonathan J. Webster, 298-322. London: Continuum.

Lalić, Dražen. 1993. Torcida-pogled iznutra. Zagreb: AGM.

Mangan, James Anthony. 1996. Tribal Identities: Nationalism, Europe, Sport. London: Frank Cass Publishers.

Martin, Jim R., and David Rose. 2003. Working with Discourse: Meaning beyond the Clause. London: Continuum.

Martin, Jim R., and Peter R. R. White. 2005. The Language of Evaluation: Appraisal in English. Hampshire: Palgrave Macmillan. 
Oktar, Lutfiye. 2001. "The ideological organisation of representational processes in the presentation of us and them.” Discourse \& Society 12 (3): 313-46. doi: 10.1177/0957926501012003003.

Pooley, John. 1978. The Sport Fan: A Social Psychology of Misbehavior. Sociology of Sport Monograph Series. Calgary: Capher.

Slobin, Mark. 1993. Subcultural Sounds. Micromusics of the West. Hannover: Wesleyan University Press.

Stets, Jan, and Peter Burke. 2000. "Identity Theory and Social Identity Theory." Social Psychology Quarterly 63 (3): 224-37.

Tajfel, Henri, ed. 1978. Differentiation between Social Groups: Studies in the Social Psychology of Intergroup Relations. London. Academic Press.

Zillmann, Dolf, Jennings Bryant, and Barry S. Sapolsky. 1989. “Enjoyment from Sports Spectatorship” In Sports, Games, and Play, edited by Jeffrey H. Goldstein, 241-78. Hillsdale, NJ: Laurence Earlbaum.

Wenger, Etienne. 2006. “Communities of Practice”. Etienne Wenger Home Page. Accessed February 21, 2014. http://www.ewenger.com/theory. 